\title{
DISKONTINUITNÍ VÝVOJ VLASTNICTVÍ K PŮDĚ OD PŘEDVÁLEČNÉ POZEMKOVÉ REFORMY DO SOUČASNOSTI
}

\section{Václav Průcha*}

\section{Karel Zeman: Vývoj vlastnictví k půdě a souvisejících procesů na území ČR od roku 1918 do současné doby}

Praha: Vysoká škola ekonomická, 2013. 316 stran. ISBN 978-80-245-195.

K nepočetným publikacím zachycujícím dlouhodobé ekonomické procesy na našem území se přiřadila Zemanova publikace, věnovaná vlastnickým vztahům k půdě. Autor v předmluvě uvádí, že se podílel „,na legislativně právním, institucionálním i vlastním realizačním procesu čtvrtého pilíre transformace národního hospodářství". V recenzované publikaci shrnul své poznatky o přeměnách vlastnictví k půdě, které probíhaly v letech 1989-2010. Odtud postupoval retrospektivně k pozemkové reformě v meziválečném období. Byl motivován rovněž „neexistenci obdobné publikace, která by prưřezově analyzovala období od roku 1918 do současné doby ve zvolené struktuře“.

Analýzu vlastnictví $\mathrm{k}$ půdě zasazuje autor do širšího rámce hospodářské politiky a majetkových přeměn v celém národním hospodářství. Zemanův výklad odráží skutečnost, že ve sledovaném období věnovaly vládnoucí politické garnitury vlastnickým vztahům $\mathrm{k}$ půdě mimořádnou pozornost.

Z názvu knihy vyplývá, že se zabývá problematikou České republiky. Ve skutečnosti sleduje do roku 1989 a z legislativního hlediska až do rozdělení České a Slovenské Federativní Republiky (ČSFR) celostátní vývoj. Výjimkou jsou léta 1939-1945, věnovaná Protektorátu Čechy a Morava se subkapitolou o Slovensku.

Výklad let 1918-2010 je rozčleněn do pěti období podle časové posloupnosti se zlomovými mezníky 1939, 1945, 1948 a 1989. Nejpodrobněji je zpracováno poslední období po roce 1989.

Za první republiky představovala největší zásah do tehdejší vlastnické struktury celého národního hospodářství pozemková reforma. Omezila hospodářské pozice i politický vliv opor habsburské monarchie - šlechty a zčásti i katolické církve. Jedním z prvních zákonů nového státu bylo zrušení šlechtických titulů, dodnes platné u občanů ČR, ale v polistopadových sdělovacích prostředcích často nerespektované. Citelné omezení zemědělské půdy a lesního majetku mělo postihnout i katolickou církev, ale s ohledem na převážně katolické Slovensko a po kampani lidové strany, Vatikánu a dalších zahraničních intervencích se tento zábor omezil na nevelkou část uvažovaného rozsahu.

\footnotetext{
* Václav Průcha (pruchavp@seznam.cz). Autor působil na katedře hospodářských dějin Vysoké školy ekonomické v Praze. V současnosti se zabývá novodobými hospodářskými a sociálními dějinami.
} 
O pozemkové reformě z první republiky poskytuje existující literatura mnohostranné informace. ${ }^{1} \mathrm{~V}$ Zemanově knize jsou však vedle rozboru stěžejních právních norem zákonů záborového, náhradového a přídělového - akcentovány i nezrrídka opomíjené problémy, zejména institucionální zajištění reformy ministerstvem zemědělství (v příloze je organizační schéma jeho IX. odboru pro pozemkovou reformu) a Státním pozemkovým úřadem. Jsou popsány úkoly úřadu, jeho organizační struktura, systém řízení a způsob financování. Pozemková reforma je analyzována podle právních norem, ale za zákony o reformě i o Státním pozemkovém úřadu, stejně jako za realizací reformy se skrývá rozhodující vliv agrární strany.

Autor hledá odpověd' na otázku, jaké byly hlavní motivy k realizaci pozemkové reformy (s. 38-39). Uvádí čtyři motivy: 1. Omezení ekonomického vlivu šlechty, římskokatolické církve, mad'arských a německých vlastníků; 2. Vytvoření sociální stability změnou vlastnické struktury zemědělské a lesní půdy; 3. Snaha nové politické garnitury získat širokou volební podporu; 4. Stabilizace nově vzniklého samostatného národního hospodářství vytvořením malého a středního podnikatelského stavu.

V knize je také otištěn statistický přehled o průběhu reformy a v závěru k meziválečnému období je ukázáno, jak se postupně vytrácel její počáteční radikalismus a reforma „, z hlediska podstaty právní úpravy“ nebyla splněna. Konstatuje, že šlo o , učebnicový př́klad" vládního selhání. K tomu možno dodat, že se nedokončení reformy promítlo až do polistopadových vlastnických úprav a zkomplikovalo je.

Jako doplněk k Zemanovu textu uvedu dvě poznámky. Vlastnických vztahů bezprostředně po ř́jjnu 1918 se týkal i v knize nezmíněný zemědělský program sociální demokracie, která tehdy „nahrála na smeč“ agrární straně požadavkem nepřidělovat zabranou velkostatkářskou půdu rolníkům do vlastnictví, ale postátnit ji a vytvářet na ní státní zemědělské podniky nebo ji pronajímat družstvům malovýrobců. Dále to byl posun v postojích vedoucích činitelů agrární strany vrůstajících do nové vrstvy velkostatkářů nešlechtického původu od éry Antonína Švehly v 20. letech k Rudolfu Beranovi a posléze až k Adolfu Hrubému, čelnému kolaborantskému členu protektorátních vlád. Tento odklon od počáteční obhajoby zájmů rolnictva k prosazování požadavků nové velkostatkářské vrstvy nešlechtického původu se netýkal jen ústupu od původního programu pozemkové reformy, ale promítal se do celkové zemědělské politiky. Nejzřetelněji se to projevilo za velké hospodářské krize v podobě státního intervencionismu, který byl v zemědělství pod taktovkou agrární strany posvěcen i legislativní cestou.

V dalším období let 1939-1945 se autor zabývá vlastnickými přeměnami všeobecně i v zemědělství odděleně v Protektorátu Čechy a Morava a na Slovensku. V českých zemích se germanizační politika okupačního režimu v oblasti pozemkového vlastnictví soustředila na vyvlastnění židovské půdy, zábory státní půdy, uvalování vnucených správ a dosazování německých správců do hospodářství českých zemědělců, na konfiskace půdy jako postihu za politické a hospodářské ,delikty“ a na vystěhování obyvatelstva z mnoha českých obcí při budování nebo rozšiřování vojenských cvičišt'. Německé vlastnictví se

$1 \quad$ Z významných publikací o pozemkové reformě a zemědělské výrobě v meziválečném období autor neuvádí základní úřední pramen, vydaný ministerstvem zemědělství v roce 1938 Dvacet let československého zemédělství 1918-1938, 272 s. a tabulka v př́loze. Prvním souhrnným zpracováním této problematiky po roce 1948 je text A. Pražského v monografii kolektivu autorů VŠE v Praze Přehled hospodářského vývoje Československa v letech 1918-1945. SNPL: Praha 1961 (1. vydání), s. 42-63, 193-209, 337-355. 
rozmnožilo i tím, že statkáři se v hojném počtu přihlašovali k německé národnosti, zlákáni různými výhodami a obnovením šlechtických titulů. Ve třech př́lohách je popsáno organizační uspořádání protektorátního ministerstva zemědělství a Pozemkového úřadu pro Čechy a Moravu.

Karel Zeman nazývá toto období válečnou pozemkovou reformou. Takové označení nepokládám za vhodné, protože reformou se tak stávají násilné zábory půdy z politických, nacionálních a rasových pohnutek. Tyto zábory byly svou podstatou loupením českého majetku a v případě židovských vlastníků, ale i mnoha dalších osob vyústily až v jejich fyzickou likvidaci. To je něco zcela odlišného od zemědělských reforem, které proběhly např. za Josefa II., v revolučním roce 1848/49 nebo v první republice.

Na Slovensku Tisův režim vyhlásil pozemkovou reformu za součást vládní politiky, ale tato pseudoreforma se nakonec smrskla na zábor židovské půdy. Z 1619 tis. ha zemědělské a lesní půdy uvažovaných zprvu pro zábor bylo rozděleno jen 2,8\% (45 379 ha, z toho 44329 ha židovské půdy). Navíc z přerozdělené půdy připadala bezmála polovina na 44 velkých protekčních přídělů o průměrné velikosti 471 ha. ${ }^{2}$

V období let 1945-1948 se Zeman zaměřuje hlavně na problematiku zemědělského majetku v prezidentských dekretech z roku 1945, které se staly odrazovým můstkem k poválečné pozemkové reformě. Především to byly dekrety o neplatnosti některých majetkoprávních rozhodnutí z doby nesvobody, o národní správě majetkových hodnot Němců, Mad'arů, zrádců a kolaborantů, o konfiskaci nepřátelského majetku a o osídlování uvolněné půdy českými, slovenskými a jinými slovanskými zemědělci. Je popsána činnost Národního pozemkového fondu při Ministerstvu zemědělství ČSR, analyzován průběh reformy a kvantifikován její rozsah.

V př́padě osídlování pohraničí se autor opírá o monografii F. Čapka aj. Nové osidlení pohraničí českých zemí po druhé světové válce (2005). Tato publikace brněnských autorů preferuje osídlování na Moravě a v úrodnějších oblastech Čech, což se odráží i v Zemanově publikaci nezahrnutím poněkud odlišné problematiky méně úrodných horských a podhorských oblastí do textu. Zde v letech 1946-1949 přechodně působilo na výměře kolem 200 tis. ha více než 150 pastvinářských družstev, která se starala o hospodářská zvířata a dodávala píci patronátním vnitrozemským okresům. Na str. 80 se Zeman zmiňuje o tom, že v průběhu roku 1947 , kritikové stále více usilovali o revizi poválečných změn v zemědělstvi a osidlení pohraniči “ (míní se např. nízká kvalifikace osídlenců, velký rozsah neobdělané půdy, hospodářské ztráty v zemědělství). Vzniká otázka, zda tomu mohlo být při výměně osídlení na velké části českého teritoria jinak, zejména uvážíme-li dobu kratší než dva roky, v níž bylo nutné v důsledku odsunu Němců nové osídlení zabezpečit.

Vlastnických vztahů se týkal také v Zemanově publikaci neuvedený zákon č. $143 \mathrm{Sb}$. z 10. července 1947 ,o převodu vlastnictví majetku hlubocké větve Schwarzenbergů na zemi Českou“. Jejich nemovitý majetek, zejména kolem 48 tis. ha lesů, přešel bez náhrady do vlastnictví tehdejší země České, která měla osobám postiženým zákonem poskytovat zaopatřovací důchod ve výši určené vládou (přijetí zákona při jeho projednávání v Národním shromáždění doporučila poslankyně za Čs. stranu národně socialistickou Milada Horáková).

2 Blíže včetně odkazů na slovenskou literaturu Faltus, Jozef - Průcha,Václav: Prehlad hospodárskeho vývoja na Slovensku 1918-1945. Bratislava 1967, s. 333-338. 
V krátké zmínce o vlivu pozemkové reformy na církevní majetek na s. 85 přebírá Zeman tvrzení z brožury M. Kalného Církevní majetek a restituce (1995), že církev přišla za nacistické okupace o své nemovitosti v pohraničí a že $\mathrm{k}$ navrácení tohoto majetku mělo dojít na základě zákona č. 5/1945 Sb. Kalného publikace psaná z pozice katolické církve patrně nikoli náhodou věnuje církevní problematice v období nacistické okupace z celých 28 stran textu pouhých 12 řádek, a i na nich zkresluje skutečnost. Na církve se po skončení války převáděly v pohraničí fary a s nimi spojený majetek, ale zároveň se předpokládala a fakticky již začala konfiskace majetku ř́mskokatolických řádů, klášterů a jiných institucí - samostatných právnických osob ${ }^{3}$, které až na mizivé výjimky (jednotlivci ve Vyšším Brodě) zradily Československo. Tyto instituce, podobně jako katolická církev v Rakousku při anšlusu v březnu 1938, vítaly připojení k Německu a podporovaly jeho agresivní, antisemitskou a germanizační politiku.

Vznikla právnická zápletka, protože zastánci katolické církve prosazovali stanovisko o univerzálnosti jejího vlastnictví, které jednotlivci nebo řády pouze spravují. Na protest proti konfiskaci poslala Apoštolská internunciatura v Praze čs. vládě řadu nót a ze zahraničí byl prezident Beneš vyzýván, aby do konfiskačního sporu zasáhl, což nebylo v jeho kompetenci. V Národním shromáždění interpelovali národně socialističtí poslanci opakovaně komunistického ministra zemědělství J. Duriše za váhavý postoj ke konfiskacím církevních objektů v pohraničí; pravdou byl spíše opak, ale tato otázka se zneužívala ve vnitropolitickém boji. Na jaře 1946 vláda rozhodla o pozastavení konfiskací, ale také o odsunu německých řeholníků vzhledem $\mathrm{k}$ jejich postoji v roce 1938 a za války. V podstatě zůstal problém konfiskací pohraničních církevních objektů a půdy v rozsahu desítek tisíc hektarů nerozhodnut a nejasnosti i soudní spory o této otázce trvají dodnes. ${ }^{4}$

Spor o majetkové otázky dále zostřil vztahy s Vatikánem, ovlivněné již nerespektováním přání SNR a čs. vlády odvolat z funkcí slovenské biskupy spjaté s lud'áckým režimem a nařízením SNR z května 1945 o postátnění soukromých škol včetně církevních na Slovensku (celostátně to bylo upraveno až v dubnu 1948). Přitom Slovensko, kde největším církevním majetkem v mad'arských rukou bylo kolem 40000 ha půdy kapituly v Ostřihomi, řešilo problém církevní půdy v mad'arských rukou mírněji než samotné Mad'arsko (tam se pozemková reforma vztahovala i na vlastnictví církve).

Čtvrtá část knihy se zabývá na 60 stranách nejdelším obdobím let 1949-1989. V ní se však na rozdíl od ostatního textu projevuje obsahová nevyváženost a rovněž nejasnost ve vymezení vlastnictví půdy. V procesu kolektivizace (1949-1960), který je popsán rok od roku, je maximum pozornosti upřeno k pronásledování tzv. kulaků, ale jiné, početnější skupiny vesnického obyvatelstva nejsou tolik zmiňovány nebo se opomíjejí. Jde např. o vstup do JZD někdejších zemědělských dělníků, drobných rolníků a početné skupiny převážně žen z rodin tzv. kovo- a stavorolníků, dále o problematiku záhumenků, odstraňování agrárního přelidnění na Slovensku a ve státním sektoru o strojní a traktorové

3 Poslanec Marek Benda, jeden z předních zastánců „církevních restitucí“, odpověděl v roce 2015 $\mathrm{v}$ televizi na otázku, bude-li katolická církev schvalovat nebo kontrolovat př́padné převody restituovaných majetků do zahraničí, že tomu tak nemůže být, protože jde o samostatné subjekty. Tedy opačná argumentace než v roce 1945.

4 Zmiňuji se podrobněji o této otázce, protože jsme svědky mnoha soudních procesů, z nichž některé končí u jednotlivých soudních instancí s opačnými výsledky. Blíže o církevních institucích v pohraničí Průcha, V. a kol.: Hospodářské a sociální dějiny Československa 1918-1992, II. díl obdobi 1945-1992. Brno: nakladatelství Doplněk 2009, s. 77-79. 
stanice včetně proměn jejich služeb pro JZD. Především měla být analyzována právní stránka vlastnictví půdy v JZD. ${ }^{5}$

Protože otázka vlastnictví půdy není přesně formulována (píše se hlavně o zabavování majetku „kulaků“), působí poněkud překvapivě slova o „,privátních vlastnících družstev“ v 80. letech (s. 151). Jinde je zmínka o „vlastnictví družstevního sektoru“, pravděpodobně bez záhumenků (s. 148, 284). Není vysvětlen pojem ,nedělitelného fondu“ v zemědělských družstvech ani zdokumentováno tvrzení o tom, že někteří zemědělci (v roce 1968 nebo po něm?) využili možnosti ,, vzít si zpět svioj majetek a hospodařit na něm tak jako před socializací a združstevňováním“ a že „převážná většina z nich“ se vrátila do družstev a ,soukromé podnikání tím ukončila“. Statistické údaje o počtu členů JZD nevykazují kolem roku 1968 znatelné výkyvy, takže mohlo jít jen o ojedinělé př́pady (časté to bylo v letech 1953-1955).

Pozornost by si zasloužil rozbor jedné z motivací kolektivizace - získat pracovní síly ze zemědělství pro jiná odvětví národního hospodářství. Mezi léty 1948 a 1960 se zmenšil celostátní počet pracovních sil v zemědělství (bez lesnictví) z 2237 tis. na 1466 tis., tedy o více než třetinu. Hrubá produkce $\mathrm{v}$ zemědělství přitom vzrostla v průběhu kolektivizace (1949-1960) i přes několikaprocentní pokles v letech 1952-1954 celkově o 34,2 \%, takže průměrný roční př́růstek činil 2,5 \% ${ }^{6}$ Hrubá produkce na 1 pracovníka v zemědělství stoupla na více než dvojnásobek (ročně o 6,2%).

Při nástupu kolektivizace je poukázáno na skutečnost, že JZD se svými rysy vymykala z tradice družstevního hnutí ve světě i u nás v minulosti. To je nesporná skutečnost, ale z citované literatury o kolektivizaci může vzniknout dojem, že se měla zachovat struktura již existujícího a u nás značně rozšířeného (ale i roztříštěného) zemědělského družstevnictví. Tato družstva však neodpovídala tehdejší socialistické orientaci hospodářské politiky. Ponecháme-li stranou nezemědělské družstevnictví nebo prvopočátky zemědělských družstev, rozhodovala $\mathrm{v}$ zemědělských družstvech a jednoznačně v družstevních centrálách agrární buržoazie. Již v roce 1921 byl z iniciativy agrární strany ustaven vrcholový orgán zemědělského družstevnictví Centrokooperativ. Podle statistiky z roku 1930 působilo v ČSR 26 druhů různorodě orientovaných zemědělských družstev s rozmanitou členskou základnou, výší upisovaných podílů a organizační strukturou. Zatímco např̀. průměrná finanční účast na jednoho člena dosahovala u potravních družstev na Slovensku (pravděpodobně s nejméně majetnou členskou základnou v ČSR) jen něco přes $100 \mathrm{Kč}$, v elektrárenských výrobních družstvech to v roce 1930 bylo $5745 \mathrm{Kč}$ a v družstevních lihovarech $2511 \mathrm{Kč}^{7}$

$5 \quad$ K vyjasnění některých důležitých okolností by přispělo obeznámení s interními diskusemi v orgánech KSČ. Zejména to byl přechod od předúnorové a bezprostředně poúnorové představě o dlouhodobější socializaci zemědělství k politice rychlé kolektivizace na podzim 1948, kdy působil i tlak SSSR, Informbyra a kampaně proti Svazu komunistů Jugoslávie. Rovněž by byl zajímavý obsah interní diskuse o vlastnictví půdy při př́ípravě Ústavy ČSSR v roce 1960 (byly odmítnuty náměty na postátnění půdy podle sovětského vzoru).

$6 \quad$ Historická statistická ročenka ČSSR. FSÚ: Praha, 1985, s. 213. Stálé ceny roku 1980. Výchozí rok 1948 ovlivnily v živočišné výrobě důsledky sucha v roce 1947. Za období 1950-1960 činil meziroční př́růstek $1,7 \%$ (vlastní výpočet).

7 Strukturu zemědělských družstev a sociální rozvrstvení jejich členstva analyzuji v článku Zemědělská družstva v meziválečném období ve světle statistiky. In Agrární strana a jeji zájmové, družstevní a peněžni organizace. Studie Slováckého muzea, Uherské Hradiště, č. 15/2010, s. $141-152$. 
K ovládnutí zemědělského družstevnictví agrární buržoazií přispívalo hlasování podle vložených podílů, takže značná část družstevníků stěží mohla činnost družstev ovlivnit. Zatímco zámožní zemědělci bývali členy i několika specializovaných družstev včetně skladištních a zpracovatelských podniků, vesnická chudina nebyla zpravidla do družstev zapojena. Domnívám se, že transformace zemědělského družstevnictví byla v tehdejších historických podmínkách nezbytná, ale mohla proběhnout odlišně, než tomu bylo na přelomu 40. a 50. let. Významnou změnu v činnosti zemědělského družstevnictví přineslo uplatnění zásady „,co člen, to hlas“.

Při popisu měnové reformy je věta: ,, Obyvatelstvo si mohlo vyměnit své staré penize za nové v kurzu 50:1" (s. 116). Chybí však zmínka o souběžném přepočtu hospodár̆ských čísel v poměru $5: 1$, takže znehodnocení by bylo $10: 1$. Ale ani to neodpovídá skutečnosti, protože část hotovostí a zejména úspor a jiných částek byla vyměňována $\mathrm{v}$ poměru $5: 1$ nebo $\mathrm{v}$ jiném poměru výhodnějším než $50: 1{ }^{8}$

V období let 1961-1989 je věnována hlavní pozornost 70. letům, kdy jsou až př́liš detailně popsány plány zemědělské výroby a jejich plnění. $V$ předcházející dekádě je zdůrazněn jako nový fenomén rozvoj přidružené výroby v JZD a nástup k procesu koncentrace a centralizace výroby, s ním spojeným slučováním JZD ve větší celky a formování zemědělsko-průmyslového komplexu. Pozornost by si zasloužily i další nastupující procesy, v nichž bylo třeba řešit i majetkové vztahy, jako byla horizontální a vertikální mezipodniková kooperace, kooperační sdružení, společné zemědělské podniky a agrokomplexy.

Zemanův rozbor postupné stabilizace JZD a dlouhodobého trendu růstu zemědělské výroby doplňuji několika skutečnostmi: Start k trvalému vzestupu výroby nastal v polovině 60. let a do roku 1989 bylo dosaženo téměř stoprocentního krytí potřeb vnitřního trhu u potravin produkovaných ve středoevropských podmínkách. ČSSR v této době předstihovala $\mathrm{v}$ dynamice růstu hrubé zemědělské výroby evropský průměr. Pozoruhodně se zlepšila věková a kvalifikační struktura pracovníků v zemědělských podnicích, což se projevilo i v úrovni jejich řízení. Zároveň mizela atraktivnost záhumenků v chovu skotu a prasat a $\mathrm{z}$ rozhodnutí samotných družstevníků se zmenšovala i výměra záhumenků. Pro českou veřejnost takřka nepozorovaně začala v horských oblastech Slovenska od roku 1971 závěrečná vlna kolektivizace, v níž se během deseti následujících let snížil počet individuálně hospodařících rolníků ze 111 tis. na 10 tis. ${ }^{9}$

Z legislativních opatření byl důležitý zákon o zemědělském družstevnictví z roku 1975 (na něj navázaly nové vzorové stanovy JZD) a v pozdějším liberálnějším klimatu zákon č. 90/1988 o zemědělském družstevnictví, který de facto jen kodifikoval posilování samostatnosti JZD, k němuž již došlo. Podle tohoto zákona hospodařila družstva s vlastním majetkem a s vlastnictvím v „družstevním užívání“. V sociální sféře se život rolníků změnil přerodem univerzálně orientovaného rolníka na pracovníka-specialistu na určitý druh činnosti. Přechodem k práci na směny se rozšířil volný čas družstevníků. Členové JZD v 80. letech již předstihovali dělníky a některé skupiny ostatních zaměstnanců např. ve velikosti nově postavených bytů a vybaveností domácností. Zároveň se rozšiřovala

8 Detailními přepočty jsem dospěl k závěru, že novou korunu získalo obyvatelstvo v průměru za 13,92 Kčs (místo za 5 Kčs vzhledem k přepočtu cen), z toho u hotovostí za 24,68 Kčs a u úspor za 8,83 Kčs. Blíže Průcha, V. a kol.: Hospodářské a sociální dějiny..., c. d., II. díl, s. $283-288$.

$9 \quad$ Historická statistická ročenka ČSSR, c.d., s. 625. 
sociální, kulturní, sportovní a rekreační činnost JZD ve prospěch členské základny i ostatního obyvatelstva venkova.

Těžištěm a také hlavním přínosem Zemanovy monografie je její pátá, nejrozsáhlejší část o období po roce 1989. Východiskem zkoumání jsou jednotlivé formy a instituce privatizačního procesu s akcentem na vlastnictví půdy. Úvodní legislativní rámec se soustřed'uje na výklad čtyř zákonů z let 1990-1991 o zmírnění některých majetkových křivd, mimosoudních rehabilitacích, přechodu některých věcí z majetku ČR do vlastnictví obcí a úpravě vlastnických vztahů $\mathrm{k}$ půdě a jinému zemědělskému majetku. Tyto zákony stanoví, čeho se restituce týkají, ale také jaká půda nebo objekty jsou z restitucí vyňaty, nebo kdy má být místo vydání věcí poskytnuta finanční náhrada. V roce 2000 pak následoval zákon o zmírnění některých majetkových křivd způsobených holocaustem. Na s. 290-294 je přetištěna prŕloha k tomuto zákonu č. 212 se seznamem 125 uměleckých děl převáděných z vlastnictví státu restituentům.

$\mathrm{Z}$ institucionálního rámce privatizační agendy jsou popsány úkoly všech privatizačních institucí se zvláštním zřetelem $\mathrm{k}$ vlastnickým změnám v zemědělství. Čtenář je seznámen s úkoly a pravomocemi ministerstev zemědělství a pro správu národního majetku a jeho privatizaci, Pozemkového fondu ČR, Ústředního pozemkového úradu a pozemkových úřadů s okresní působností.

Autor se nespokojil shrnutím a výkladem jednotlivých privatizačních a restitučních opatření, ale hodnotí je též na základě vlastní zkušenosti z př́ípravných prací. Uvádí pohnutky přijímaných řešení, ale upozorňuje i na různá úskalí a problematické momenty, a z národohospodářského hlediska důrazně kritizuje mechanismus církevních restitucí, zejména s ohledem na jednoznačná stanoviska ústavních právníků týkajících se legitimity restitucí katolické církve, na diametrální zvýhodňování církví oproti ostatním oprávněným osobám. Kniha byla dopsána před schválením zákona o vyrovnání s církvemi, ale v době, kdy již bylo známé znění zákona vráceného Senátem zpět do Sněmovny. Karel Zeman varoval, že ,,zákon by založil nové křivdy a zásadní nerovnost před zákonem mezi všemi běžnými restituenty na jedné straně a církvemi na straně druhé". V závěrečném odstavci celé knihy jsou slova, že ,,schváleni této nekorektní normy ... by vrhlo velmi negativni stín na celý čtvrtý pilír transformace českého národního hospodářství, tedy na celé období změn vlastnických vztahü“ (s. 257).

Karel Zeman, jak je to obvyklé i v jeho minulých publikacích, přináší bezpočet statistických informací o zkoumaných jevech. Vedle více než 40 textových tabulek a 82 grafů zařadil do příloh 22 rozsáhlých tabulek, z nichž část dokumentuje každoročně až do roku 2010 postup privatizační agendy v celém národním hospodářství a další tabulky postup restitucí; v př́lloze 11 je zachyceno i regionální rozložení restitucí podle okresů ČR koncem roku 2009. K tabulkám mám jedinou připomínku, že u zemědělské výroby (zejména její rostlinné složky) je věrohodnější eliminovat roční výkyvy několikaletými průměry. U grafů, pokud ilustrují jen nepatrný pohyb, jsou výstižnější tabulky.

Restituce pozemkového majetku bývalé šlechty nejsou předmětem zvláštní kapitoly patrně proto, že na rozdíl od církevní problematiky nebyly řešeny samostatnou právní normou, nýbrž realizovány podle všech restitučních zákonů. ${ }^{10}$

10 O této problematice je $\mathrm{k}$ dispozici rozsáhlá monografie Josefa Bendy: Restituce majetku bývalých šlechtických rodů po roce 1989 (Studie Národohospodářského ústavu Josefa Hlávky 8/2010,

574 s.). O knize byla veřejná diskuse v Parlamentu ČR za účasti mnoha poslanců a předních českých právníků. Benda mj. kritizuje převažující mediální obraz této problematiky, „kde docházi 
Z drobných připomínek upozorňuji na nečitelné údaje na mapkách (s. 273-274) a na několik překlepů. Na s. 32 náhrady deputátníků na rozparcelovaných velkostatcích činily v průměru 5173 Kč. Graf 4.11 ukazuje výkony na 1 ha zemědělské (nikoli nezemědělské) půdy. Mezi překlepy lze asi zařadit i zmínku o oslabení ortodoxních a prosazování reformních ekonomů „,po roce 1968“ (reformní ekonomové se prosazovali před rokem 1968 a v tomto roce, později byli umlčeni). Odkazy na literaturu se omezují na název publikace a rok vydání, takže jejich ověření je pracné.

Zemanova monografie je z mnoha aspektů významným a originálním přínosem pro poznání ekonomických procesů ve sféře vlastnických vztahů, které probíhaly v Československu a po roce 1992 v ČR. Vedle faktografie hledá autor jejich ekonomické a politické kořeny i souvislosti. Do roku 1989 se většinou opírá o poznatky z existující literatury a doplňuje je, ale jeho pojetí a výklad polistopadového transformačního procesu v oblasti vlastnických vztahů $\mathrm{k}$ půdě jsou autentickým příspěvkem $\mathrm{k}$ hlubšímu poznání východisek, průběhu, ale i kladů a slabin uskutečněných přeměn. Plně využil svých zkušeností z týmu odborníků koncipujících reformy, dokázal poznatky systemizovat a přehledně je podat čtenářům. Stylistická a jazyková úroveň textu je na vysoké úrovni, což je třeba ocenit za současného všeobecného úpadku jazykové kultury v ČR. Autor využívá široký okruh odborné literatury, i když mohl k některým tvrzením z ní převzatých zaujmout kritický postoj. Stejně jako v dřívějších Zemanových publikacích je i zde příkladná práce s číselnými údaji, jejichž shromáždění, utřídění a seskupení do mnoha tabulek s každoročními údaji vyžadovalo jistě mravenčí práci. Rozsáhlé tabulky v př́lohách se stanou neocenitelnou pomocí pro ty ekonomy, hospodářské historiky, právníky a další odborníky, ale i studenty, kteří se zabývají vlastnickými přeměnami po roce 1989. Autorův záměr, naznačený v prvním odstavci recenze - vyplnit mezeru v jedné oblasti průřrezových prací z našich hospodářských dějin - se podařilo splnit.

$\mathrm{Na}$ recenzovanou knihu Karel Zeman navázal dalšími dvěma monografiemi, které všechny tři dohromady tvoří neoddělitelný celek. Analýza privatizačního procesu v České republice (Karolinum 2015, ISBN 978-80-246-2939-1) zkoumá privatizační proces z právního, institucionálního, věcného, statistického a makroekonomického hlediska. Monografie tedy komplexně zkoumá privatizační proces v ČR, tj. malou privatizaci realizovanou Ministerstvem privatizace $\breve{C}$, velkou privatizaci realizovanou Fondem národního majetku ČR, velkou privatizaci realizovanou Pozemkovým fondem ČR a privatizaci akcií prostřednictvím kuponů realizovanou Ministerstvem financí ČR. Analýza restitučních procesů v České republice (Karolinum 2015, ISBN 978-80-246-2954-4) zkoumá z právního, institucionálního, věcného, statistického a makroekonomického hlediska všech šest restitučních procesů, proces likvidací a konkurzů státních podniků a proces transformace státního majetku do vlastnictví obcí. Kolekce těchto tří monografií komplexně pokrývá turbulence ve změnách vlastnických práv na území ČR od roku 1918 do současné doby, proto je z hlediska správného pochopení moderních hospodářských dějin ČR po roce 1989 a s ohledem na ojedinělost zmíněných monografií nutné tyto tři provázané knihy studovat současně.

k pozoruhodným vybočením z objektivity informováni" (s. 18). Václav Pavlíček v obsáhlé předmluvě konstatuje: „Restaurační trend v právu zahájený po listopadu 1989 se tehdy dožadoval návratu k demokratickým tradicím první republiky a takto byl také společností prijímán. Postupně však zasahoval hlouběji do minulosti a někdy pod hesly odstraněni »komunistických « zásahů prosazuje hodnoty protikladné demokraticko-republikánské státnosti zrozené v roce 1918 a prosazované zakladateli Československa“" (s. 181). 